\title{
食の外部化に抢ける若者の生活スタイルと食意識に 関する研究
}

\author{
梶原 公子 \\ (聖徳大学大学院人間栄養学研究科)
}

\section{People's life-style and awareness on eating concerned with a study of the young "Shoku-no-gaibuka"}

\author{
Kimiko Kajiwara \\ The Graduate School of Human Nutritional Science Seitoku University
}

干271-8555 松戸市岩瀬 550

\begin{abstract}
Recent years, the young often eat meals outside their home. When "Shoku-noGaibuka" increases, it seems that the young's awareness on eating changes. This study was undertaken to investigate the "Shoku-no-Gaibuka" aspect on the part of young people. An interview survey was conducted with special focus being placed on each interviewee's personality and life-style. The interview sample included 52 young peoples 20-25 years old living in the Metropolitan area. Twenty six of the subjects were men and 26 were women. The result of the interview showed that about $30 \%$ at the young usually eat meals away from home. Many of them work until very late at night, moreover they do not eat breakfast. The amount of "Shoku-no-Gaibuka" is not related to the awareness of eating, but the young who usually eat these meals have less interest in their dietary culture and spiritual aspect. The young who usually eat "Shoku-no-Gaibuka" in addition to being unsatisfied with the meal, desire an improvement in their dietary conditions.
\end{abstract}

\section{1 緒 言}

今日の食事が，かつてと比べて最も変化した点は，こ れまでは生鮮食料品を家庭の台所で調理し食べていたの が，外食産業が提供する外食メニューに代替されるよう になったこと，言い換えるなら食が外部化されるように なったことである1)。ことに 20 代はコンビニ世代2) と呼 ばれるように，食の外部化の度合いが高い世代と考えら れる。コンビニ食の利用をはじめ, 食事を家庭外で摂る ことは，食習慣やライフスタイルとの関連から，現在で も肯定的に受け止められているとはいい難い。小林は男 子大学生の食習慣やライフスタイルの偏り, 乱れが著し いこと, 彼らに動脈硬化疾患のリスクが増加しているこ とを報告している3）。同時に食習慣や生活の乱れが健康 リスクを招来させる危険性を孕むことから，栄養教育の 必要性を強調している。

しかしながら，10代後半から 20 代前半は病気に対する 有訴率が最も低い年代であることや，食べたい時，いつ
でも食べ物が入手できる時代であることなどから, 若者 に対しては栄養病理の側面と栄養や健康リスクを関連さ せ, 規則正しい食事や栄養バランスの必要性を訴える方 法には, 限界があるものと考えられる。しかしその一方 で，食の外部化の度合いが高くなることは，効率的で簡 便な食事が当然視され，外部化された食事に依存すると いうような,これまでとは異なった食行動の増大が懸念 される。

このようなことから本論では食の外部化という構造変 化の中で, 若者の「生活の乱れ」とともに派生している 健康リスクを考慮し, 生活スタイルと食意識がどのよう に関係しているのかを中心に検討したい。その際「食の 外部化」をキーワードとして用いる。食の外部化には次 のようなアプローチがある。

石毛直道は民俗学の概念を借用して, 外食/内食, 八 レ/ケという二組の対立する場面を用い, ハレの外食 (料亭, レストラン), ケの外食 (食堂, 給食), ハレの 内食 (家宴, 行事食), ケの内食（日常の食事）という 
4 象限の食の場を設定し，実際の食生活に沿った検討を している4)。また，国民経済べースでの食糧消費のあり よう，すなわち外食費と中食費の家計に占好飲食料費 支出の比率（食の外部化率）から反るというものである。

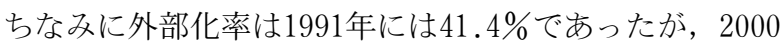
年には $45.1 \%$ に増加し, 近年食事の外部化が進んでいる ことが分かる5 。ささらに，『国民栄養の現状（平成14年 度厚生労働省国民栄養調查結果)』では, 昼食の外食率 を調査している6)。ここでの外食率は, 外食と調理済み 食品を合わせたものをもとにして抢り，その結果をみる と 20〜40歳代の男性のうち 5 割以上が㡺食は外食であっ た。

これらを踏をえ,ここでの「食の外部化」とは，家庭 内で調理, 供される内食に対する食事とし, 家庭外で調 理, 供される食事（外食全般及び調理済久食品, コンビ 二などの中食）に依存する傾向を指すものとする。

さらに大学生を対象とした食生活の実態及び食意識に 関する先行研究には，次のようなことが明らかにされて いる。

飯田らは大学生の食嗜好, 食習慣の意識調查及び食生 活の実態調查を行っている77。その結果, 日常の食事に 対する男女共通の意識として「不規則である」「食べた いものを食べている」という喏好中心であると指摘して いる。また「食事に時間をかけたい（特に女子）」と思 いつつ，「家族と時間がずれること」を気にせず，「孤食」 を肯定しているとも報告している。また，渡辺らは男女 大学生の食事時間の位置づけと食事内容, 食事形態の実 態調查を行っている8)。それによると, 男女学生の䒜食 時間はほとんぞ24時間すべてに分散し, 男子学生のほう が食事時間に対する認識の乱れが大きいとしている。ま た, 田辺らの「大学生に打ける食の満足感に影響を及ほ す因子」では，大学生は「一人でテレビを見ながら，お いしく手軽なものを食べるという傾向が見られる」と報 告している9)。

これらの先行研究を踏まえ, 本論文では次の点を明ら かにすることによって, 高校家庭科での食物分野（以下 食物教育と記述）をより有効なものにするための一助と したい。

(1) 若者の食事はどの程度，外部化されているのか。 また, 食の外部化は, 生活スタイル (生活時間, 就労形 態なぞ）とどのように関係するのか。特に，食の外部化 の高い者は生活スタイルに㧈いてどのような点が共通し ているのか。

(2) 食の外部化が高い者と高くない者では, 食意識に 沶いてどのような点で異なるのか。また，食の外部化の 高い者でそれに満足している者と満足していない者とで は，食意識にどのような違いがあるのか。

(3) 食の外部化はどのような要因が強く作用している のか，またどのような食物教育が有効であるのか。

\section{2 方 法}

\section{（1）調査対象者の選定}

調査方法は，すでに本誌で筆者が報告したものと同様 に10)，以下のように行った。

調査対象者は首都圏を中心とした 7 都県（静岡，神奈 川, 東京, 埼玉，千葉，杤木，茨城）に居住する $20 ２ 5$ 歳の男女で, 割合は $1 ： 1$ とした。また勤労者と非勤労 者（主として学生）の割合も 1：1 とした。例数は男性 の労働者と非労働者それぞれ13人, 女性の労働者と非労 働者それぞれ 13 人の合計 52 人とした。抽出方法は 5 都県 の 9 大学， 3 高校の在学生名簿及び卒業生名簿の中から, 連絡先の明らかな者を抽出し, 直接電話にてインタビ ューを申し込んだ。調査期間は2003年11月13日から2004 年 6 月 29 日までであった。調査対象者の平均年齢は 22.4 歳, 家族同居者は 28 人, 一人暮らしは 21 人, 寮生活者 3 人であった。また，労働者 26 人の職業及びその他の属性 は表 1 の通りである。

\section{(2) 調查方法}

調査対象者一人一人に対面式の聞き取り調査を行った。 質問項目は表 2 の通りである。インタビューに抢ける調 查対象者の回答内容から，共通する本質的要因を抽出し， 食の外部化の側面加彼らの食生活の具体的ありようと 食に関する意識について検討した。

な抢，本論に抢ける「外部化された食事」とは，内食 に対立した食事を指すものとした。「食の外部化」とは, 『国民栄養の現状』が示す「外食と調理済及食品を合わ せた食事」を摂る傾向が高いことを指し，通常の食事が ぞのくらい外部化された食事であるのか，その頻度ない しは程度を指すものとした。さらに「外部化された食事」 とは具体的には，スーパーやコンビニエンス・ストアー の惣菜, 弁当, 調理済及食品などの中食及び外食産業が 提供する外食を合わせた食事を指すものとした。

\section{3 結 果}

\section{（1） 食の外部化の類型}

若者 52 人を調查対象者として, 質問(1)を行ない, 日常 食がどの程度外部化されているのかについて検討した。

検討に際しては，食事時間は学校や仕事のある日と休 日とでは異なる場合が多いことから，学校や仕事のある 日の食事を対象にした。また，学生でアルバイトをする など，日によって異なる場合は，週のうち 4 日以上同じ 食事を対象とした。また，食事とは飲久物だけや，ヨー グルトや果物だけは指さずに，少なくとも主食と主菜な いしは汁物があることを要件とした。

当初, 検討にあたって一日三食食べることを前提と考 えていた。しかし，回答内容から若者は必ずしも一日三 食食べているわけではなく, 朝食欠食がかなりの割合で 存在することがわかった。そのため，一日三食型の者々 二食型（朝食欠食型）の者とを別に扱う必要があると考 
表 1 調査対象者の 52 人（男性労働者 13 人, 非労働者 13 人, 女性労働者 13 人, 非労働者 13 人) の属性

(1) 年齢 平均 22.4 歳

\begin{tabular}{c|c|c|c}
\hline 歳 & 男性 & 女性 & 合計 \\
\hline 20 & 8 & 0 & 8 \\
21 & 1 & 1 & 2 \\
22 & 7 & 12 & 19 \\
23 & 1 & 10 & 11 \\
24 & 4 & 1 & 5 \\
25 & 5 & 2 & 7 \\
\hline 計 & 26 & 26 & 52 \\
\hline
\end{tabular}

(2) 居住地域

\begin{tabular}{l|c|c|c}
\hline \multicolumn{1}{c}{ 居住地域 } & \multicolumn{2}{c}{ 単位, 人) } \\
\hline 都道府県名 & 男性 & 女性 & 合計 \\
\hline 静岡県 & 11 & 8 & 19 \\
神奈川県 & 4 & 4 & 8 \\
東京都 & 6 & 3 & 9 \\
埼玉県 & 3 & 2 & 5 \\
千葉県 & 1 & 7 & 8 \\
杤木県 & 1 & 0 & 1 \\
茨城県 & 0 & 2 & 2 \\
\hline 合計 & 26 & 26 & 52 \\
\hline
\end{tabular}

(3) 居住形態

\begin{tabular}{l|c|c|c}
\hline \multicolumn{1}{c|}{ 態 } & 男性 & 女性 & 合計 \\
\hline 家族と同居 & 10 & 18 & 28 \\
ひとり暮らし & 13 & 8 & 21 \\
寮 & 3 & 0 & 3 \\
\hline 合 計 & 26 & 26 & 52 \\
\hline
\end{tabular}

(4) 労働者 26 人の職種

\begin{tabular}{|c|c|}
\hline 女＼cjkstart性 & 人数 \\
\hline 大学院浪人 & 1 \\
\hline 映像技術者 & 1 \\
\hline 実習助手 & 1 \\
\hline 歯科助手 & 1 \\
\hline 事務職 & 4 \\
\hline 接客販売業 & 2 \\
\hline 介護職 & 1 \\
\hline 販売員 & 2 \\
\hline 小 計 & 13 \\
\hline 男性 & 人数 \\
\hline 製造工場労働者 & 2 \\
\hline 鉄道従事者 & 1 \\
\hline 公務員 & 1 \\
\hline 事務職 ～ & 3 \\
\hline 通信業営業職 & 1 \\
\hline 機械技術者 & 1 \\
\hline 運送業従事者 & 2 \\
\hline 飲食店従業員 & 2 \\
\hline 小 計 & 13 \\
\hline 合計 & 26 \\
\hline
\end{tabular}

\section{表 2 質問項目}

(1) あなたは, 現在日常の朝食, 昼食, 夕食をどのような食事（家庭内食であるのか, 外食, 調理済み食品であるのか, また 食事内容はどのようなものか）をどこで何時ごろ食べていますか。それらの食事時間はおよそ何時くらいで，ほぼ規則正し いですか。

(2) あなたが朝食を摂らないのは，ぞのような理由によるものですか。

(3) あなたは自分の食生活に満足していますか。満足しているとしたら，それはどのような点で，満足していないとしたらそ れはどのような点ですか。

えた。その際二食型（朝食欠食者と久なすこと）の判定 基準として，『国民栄養の現状』の基準をもとに，次の 4 項目を本調査独自に設定した。

(1) 少なくとも 3 ヶ月くらい習慣化している者

(2) 何も食べない者の他, お茶やコーヒー, ジュース, 果物だけの者

(3) 週のうち 4 日以上食べない者

(4) 朝食の時間帯，つまり午前11時以前に食事をしな い

上記の基準に沿って二食型を判定した後，食事内容を 検討し，その結果次の 6 つに類型化した。

$$
\text { 一日三食型 }
$$

A : 朝食, 昼食, 夕食がほとんど毎日家庭内食の者。 あるいは, 週のうち 3 日程度, 昼食だけ外食の者。

B：朝食は必ず家庭内食だが，昼食と夕食のどちらか がほぼ毎日外食の者。あるいは, 朝食は必ず家庭 内食だが，昼食はほぼ毎日外食でかつ夕食も週の うち 3 日程度外食の者。

C : 朝食は家庭内食だが，昼食と夕食が外食の者。あ るいは朝食, 昼食, 夕食とも外食の者。

\section{一日二食型}

D : 昼食, 夕食ともほぼ家庭内食の者。

$\mathrm{E}$ ：昼食か夕食のいずれかがほぼ外食の者。

$\mathrm{F}$ ：昼食，夕食ともにほぼ外食の者。 
上記の人数を示したものが表 3 である。表 3 から次の点が確 認できた。

(1) 一日三食型は，全体の 6 割強で，そのうち女性が 6 割以上を占める。

(2)一日三食型は，食の外部 化傾向の低いA，B該当 する者が多く, 外部化傾向 の高いCに該当する者は少 ない。

(3) 一日二食型（朝食欠食型）は全体の $36 \%$ 以上であ り，そのうち男性が 7 割を占める。

(4) 一日二食型は, 食の外部化傾向の高い $\mathrm{F}$ に該当す る者が多く，外部化傾向の低い $\mathrm{D}, \mathrm{E}$ に該当する者 は少ない。

(5) C と Fに該当する者は食の外部化の高い者と捉え

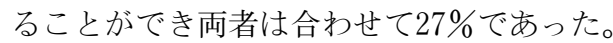

表 3 若者52人に対する「あなたは朝食, 昼食, 夕食をどのよ うな内容のものを, 何時ごろ, どこで食べますか」とい う質問に対する回答の食の外部化別分類

\begin{tabular}{|c|c|c|c|}
\hline & 分類 & 人数 (男/女) & $\%$ \\
\hline \multirow{4}{*}{ 三食型 } & A & $13(2 / 11)$ & 25.0 \\
\hline & B & $17(7 / 10)$ & 32.7 \\
\hline & $\mathrm{C}$ & $3(3 / 0)$ & 5.8 \\
\hline & 小計 & $33(12 / 21)$ & 63.4 \\
\hline \multirow{4}{*}{ 二食型 } & $\mathrm{D}$ & $2(1 / 1)$ & 3.8 \\
\hline & $\mathrm{E}$ & $6(4 / 2)$ & 11.5 \\
\hline & $\mathrm{F}$ & $11(9 / 2)$ & 21.2 \\
\hline & 小計 & $19(14 / 5)$ & 36.6 \\
\hline \multicolumn{2}{|l|}{ 合 } & $52(26 / 26)$ & 100.0 \\
\hline
\end{tabular}

\section{（2）食の外部化の理由と生活スタイル}

食の外部化が高くなるにはどのようなことが原因し， そこは生活スタイルにおいてどのような共通点が見出さ れるかについて検討した。

表 3 の結果から，外部化が高い者は 14 人 (27\%) で, このうち一日二食型（朝食欠食）は11人であった。また， 二食型は全体のうち 19 人 $(36 \%)$ を占めた。これらの結 果から食の外部化と朝食欠食との関係について検討した。 その際，朝食欠食の理由は欠食者すべてが同じではなく， 生活スタイルや若者の個々の現実生活がさまざまに反映 するのではないかと考えた。したがって朝食欠食を必ず しも好ましくない食生活,「乱れた」生活の現われとい う解釈はしないこととし，その理由を個別に聞き取るこ とにした。

一日二食型（朝食欠食者）に該当する者 19 人に欠食理 $62(62)$
由を質問した結果, 理由はほぼ次の 3 つのタイプに分け ることができた。

$\mathrm{G}$ : 生理的に食欲がなく, 食べられない...2 人（男性 2)

$\mathrm{H}$ : 朝は食べないのが習慣になっている $\cdots 8$ 人（男性 5 人，女性 3 人)

I：仕事上時間が制約されるため $\cdots 9$ 人（男性 7 人, 女性 2 人)

上記 3 つのタイプの欠食理由で，Gに当たる場合を生 理的原因によるやむを得ず型，Hに当たる場合を自己の 生活を優先した意図的選択型，I に当たる場合を仕事そ のものが欠食を誘発させる型と捉えることにした。G， $\mathrm{H}, \quad \mathrm{I}$ という理由別に, 一日二食型（朝食欠食者）の者 を食の外部化の程度別にまとめたものが表 4 である。

3つの欠食理由のなかで，I に該当する仕事が欠食を 誘発させるタイプ 9 人は, 全員が食の外部化の高いFに 属する者であった。この 9 人は, 就労形態が夜遅い仕事 に就き, 仕事が生活時間を規制するため, 朝食欠食も招 くという点で生活スタイルに共通点を見出すことができ た。

外部化が高い者で残る 5 人のうちの 3 人は, 次の点で 共通していた。第一に朝食欠食者ではないこと, 第二に 一日の生活時間が仕事, アルバイト, 学業, 部活動など にほとんど費やされ，自炊する時間はもちろん食事にか けるゆとりが極めて少ないことであった。さらに残る 2 人は, 仕事が日勤の労働者と夜のアルバイトなどのない 学生で, ともに一人暮らしで, 朝早く起きたくない, 朝 食を準備するのが面倒くさいという理由から朝食は食べ ず，昼食，夕食ともほぼ外食であった。

以上の結果から，食の外部化の高い者 14 人の生活スタ イルは，次の 3 つのパターンに分けることができた。

(1) 就労形態が夜遅く，仕事が生活時間を規制するた め, 朝食欠食が多い生活スタイル $\cdots 9$ 人

(2) 仕事, アルバイト, 学業, 部活動などで生活時間 のほとんどが費やされる生活スタイル‥ 3 人

(3) 生活時間には比較的ゆとりがあるが, 朝食は欠食 し, 昼食, 夕食も外食の生活スタイル $\cdots 2$ 人

\section{（3）食の外部化の程度と食意識}

食生活の満足感に関する質問(3)を行った結果，本調査 では, 現在の食生活に満足している者は全体の $42.3 \%$ で 
表 5-1 若者52人に対する「あなたは自分の食生活に満足していますか」と いう質問の食の外部化別回答結果

\begin{tabular}{c|c|c|l|l}
\hline & 満 足 & 不満足 & 半分満足 & 合 計 \\
\hline $\begin{array}{l}\text { 食の外部化傾向の高い者（表 } 3 \\
\text { のC， F 該当者） }\end{array}$ & $5(9.6)$ & $9(17.3)$ & 0 & $14(26.9)$ \\
$\begin{array}{l}\text { 食の外部化傾向の高くない者 } \\
\text { (表 } 3 \text { の A, B, D, E 該当者) }\end{array}$ & $15(28.9)$ & $14(26.9)$ & $9(17.3)$ & $38(73.1)$ \\
\hline 合 計 & $20(38.5)$ & $23(44.2)$ & $9(17.3)$ & $52(100)$ \\
\hline
\end{tabular}

$\chi^{2}=5.09 \quad \mathrm{p}<0.1$

表 5-2 若者52人に対する「あなたは自分の食生活に満足していますか」と いう質問の居住形態別回答結果

\begin{tabular}{c|r|r|c|c}
\hline & \multicolumn{1}{|c|}{ 満 足 } & 不満足 & 半分満足 & 合 計 \\
\hline 家族同居者 & $16(30.8)$ & $7(13.4)$ & $5(9.6)$ & $28(53.8)$ \\
一人暮らし及び寮生活者 & $6(11.5)$ & $16(30.8)$ & $2(3.9)$ & $24(46.2)$ \\
\hline 合 計 & $22(42.3)$ & $23(44.2)$ & $7(13.5)$ & $52(100)$ \\
\hline
\end{tabular}

$\chi^{2}=9.09 \quad \mathrm{p}<0.1$

あった。飯田らの大学生 508 人に対する調査結果では, 男女とも現在の食事に「満足」している者は $50 \%$ に満た ないとし，本調査は飯田らの結果に近かった ${ }^{11) 。 ~}$

質問(3)の結果をもとに，食の満足感を外部化の程度別 及び居住形態別に比較した。外部化の程度別の結果は表 5-1, 居住形態別の結果は表 5-2のとおりであった。

表 5-1 から, 食の外部化が低いほうが食生活の満足 感が高いこと, 表 5-2の居住形態別から, 家族同居者 は一人暮らしよりも満足感が高いことがわかる。食の満 足度は家族同居であるから高くなるといえるし，満足度 が高くなるから家族同居をしているというように，両者 は容易に関係があると思われる。また，食の外部化の高
い者，高くない者それぞれで満足/不満足 な者の具体的回答内容をまとめた。その結 果は表 6-1，2である（なお，「半分満足」 の者は表には入れていない)。二つの表か ら，外部化が高い者で食生活に満足してい ない者の食への関心は，食の外部化が高く ない者より「栄養, 健康」「食事形態」に 多く，「食生活」や「食事観」など文化的， 心理的関心が少ないという特徵が見られた。

\section{4 考察}

\section{（1）若者の「生活の乱れ」論}

これまでの結果から食の外部化の高い者 は, 夜型の生活, 朝食欠食, 過密な生活時 間など「生活の乱れ」と結びつきやすい特 徵が見られた。一般的に「生活の乱れ」の 原因は, 若者特有の私生活中心主義的生活 観に求められがちで, 問題を孕んでいる。

朝食欠食について見ると, 食の外部化の 高い者のうち 8 割を占めて抢り, 調査対象 者全体では36\%を超えていた。朝食欠食に関する他の データを見ると次のようである。

『平成14年国民栄養の現状』では20～29歳の朝食欠食 率は, 男性 $26.5 \%$, 女性 $20.6 \%$ で, 男女ともどの年齢層 よりも多い12)。『国民栄養の現状』は, 調査対象者の居 住地は全国に渡り, 職種もさまざまである。都市部に居 住する大学生を対象とした調査結果は次のようである。 堀田の1989年から1994年にかけて, 三重県内居住の大学 生 3000 人余りを対象に食生活を調査した結果によると, 1989年では75.3\%，1994年では63.9\%と報告されてい る13)。また田村らは, 首都圈居住の大学生を対象として 調査しているが, 自宅通学の男子学生は $65 \%$, 女子学生

表 6-1 食の外部化の高い者14人に対して「あなたが食生活で満足している場合それはどのような点 で，不満な場合それはどのような点ですか」という質問の具体的回答（複数回答を含む）

\begin{tabular}{|c|c|}
\hline 満足している者の回答内容（人数） & 不満足な者の回答内容（人数） \\
\hline $\begin{array}{l}\text { ·食生活では特に何も感じない（2） } \\
\text { ·栄養バランスが悪いと思うが満足（1） } \\
\text { ·肥満傾向が気になるが満足（1） }\end{array}$ & $\begin{array}{l}\text { 栄養·健康面（6） } \\
\text { ·栄養が偏っている，野菜不足 } \\
\text { ·体にいいものを摂っていない } \\
\text { 食事形態について（6） } \\
\text { ·食事が不規則 } \\
\text { ·ファーストフードやコンビニ食が多い } \\
\text { ·外食, 孤食が多い, 朝食を摂っていない } \\
\text { 食生活や食事観について（2） } \\
\text { ·毎日食べることを考えるのが面倒 } \\
\text { ·使った分だけエネルギ一補給すればよい } \\
\text { 料理について（1） } \\
\text { ·自炊したい } \\
\text { 経済面（1） } \\
\text { ·食費が限られている }\end{array}$ \\
\hline 計 & $\begin{array}{lll}\text { 合 } & \text { 計 } & 16\end{array}$ \\
\hline
\end{tabular}


表 6-2 食の外部化の高くない者38人に対して「あなたが食生活に満足している場合, それはどのよ うな点で, 満足していない場合それはどのような点ですか」という質問の具体的回答

(複数回答を含む)

\begin{tabular}{|c|c|}
\hline 満足している者の回答内容（人数） & 不満足な者の回答内容（人数） \\
\hline 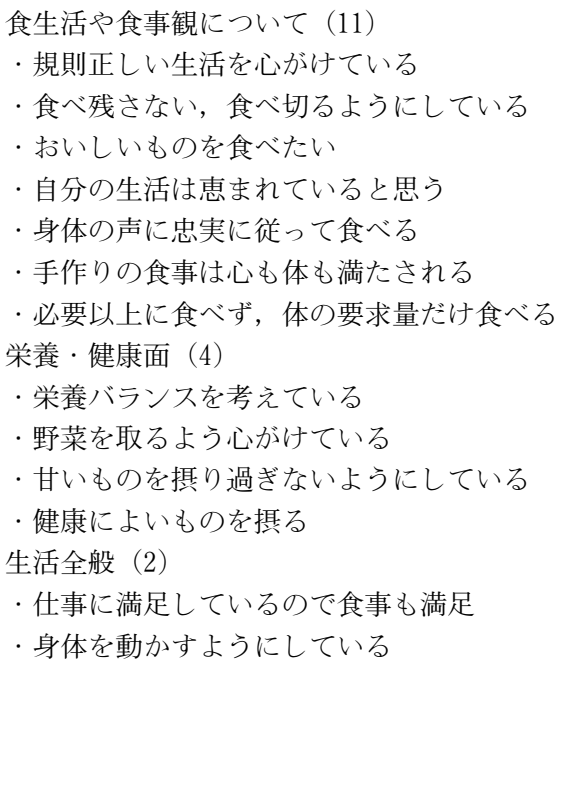 & 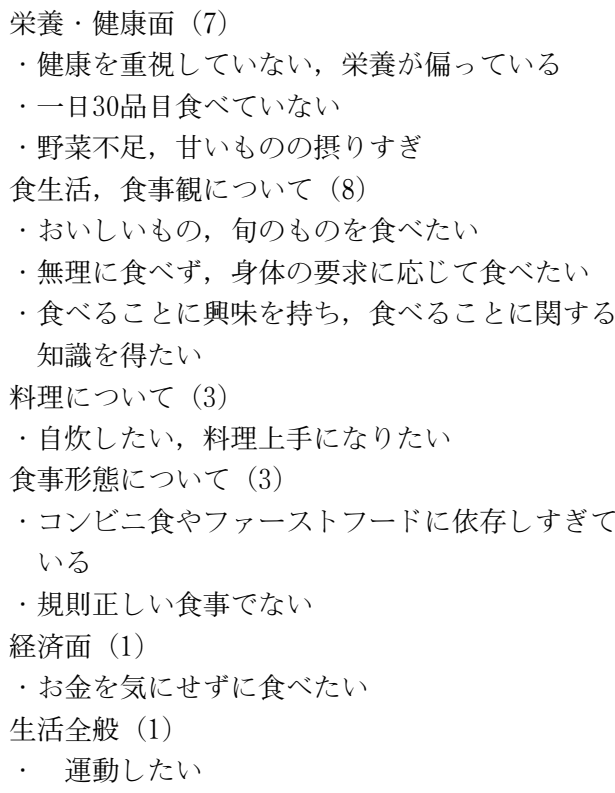 \\
\hline 17 & 計 \\
\hline
\end{tabular}

は $52 \%$ と報告している ${ }^{14)}$ 。これらの調査結果は，調査対 象者の属性によって数值に開きはあるものの，男性の方 が女性よりも高い点，また『平成14年国民栄養の現状』 の結果から若者全般に高い点で本調査と共通している。

朝食欠食をどのように見るかはさまざまである15)。し かし栄養学の立場では, 必要論が主流であり, EBM （根拠に基づく医療）という考え方から，その重要性が 強調されている16)。これに対して, 通常の生活認識や教 育的見地からは，朝食制食は生活のリズムや時間など生 活スタイルを規定する要因と位置づけられることが多い。 したがって朝食を食べるのはごく自然の営み，習慣であ り，規則正しい生活リズムを保っているのかぞうかを見 る上でのひとつの指標という捉え方が一般的であうう。 この一般論からすると朝食欠食は「生活の乱れ」と結び 付けられがちで, 朝食欠食率の高い若者は食の外部化も 高く，生活スタイルの乱れであるとみなされることにな る。

しかしながら，聞き取り調査から朝食欠食は必ずしも 「生活の乱れ」とは捉えきれない場合のあることがわか った。それは欠食には理由があるためである。

本調査では対象者の欠食をカウントする際, 何をもっ て欠食であるとするのか，欠食の基準設定を行った。欠 食の基準には「食事」とはどのようなものを指すのか， という食事概念の規定や何時に食べたものを朝食と久な すか，という時間の規定も必要である。調査では聞き取 る場合，「朝食は何時に食べますか」という質問をした。 この場合，インタビューは彼/彼女が「朝食」として食
べた時間を答える。しかし彼らが「朝食」として食べた とする時間が，世間一般の生活時間のうえからみると， 昼食時間に相当する場合があったため, 午前11時以降の 契食は昼食と及なした。さらに何かの都合で一時的に朝 食を食べなかった（食べられなかった）場合と，習慣と して一定期間以上欠食である場合とは区別する必要があ る。本調查では「通常の生活の場合」という聞き方をし， 通常とは 3 ヶ月くらい継続的に朝食を食べない状態が続 き，習慣化している場合とした。また，通常は食べるが， 休日なぞ時として「ブランチ」にすると答えた者は，日 常的に朝食は食べているためカウントしなかった。しか し, 夜遅いアルバイトのため, 週のうち 4 回以上起床が 遅く, 朝食は11時ごろ食べる, というような場合は欠食 にカウントした。

このように検討していった結果, 欠食は数值だけで捉 えるのではなく，その理由に注目する必要のあることが わかった。インタビューでは同時に欠食理由を聞いた。 その結果から朝食欠食が一概に「生活の乱れ」とはいえ ず，「欠食」には一括りに捉えきれないさまざまな事情 のあることがわかった。

結果で述べたように，欠食理由は 3 つのタイプに類型 化することができた。一般的に代謝の量や速度には個人 差があることなどから，朝食摂取が生理的に不適合であ る者は一定程度存在するのではないかと考えられ，欠食 理由のひとつ目は生理的理由によるやむを得ず型とした （結果(1)に打情）。このタイプに属する者で，食の外 部化が高い者はいなかった。これに対して，時間的ゆと 
りや契食できる状況があるにもかかわらず，食べないこ とを選択しているタイプがあった。これはいわゆる「乱 れた」生活や私生活中心主義と結び付けて捉えることが できると考え, 自己の生活を優先した意図的選択型とし た。これに該当する者は 8 人で，そのうち 2 人 $(4 \%)$ が食の外部化の高い者だった〈結果(1)に抢ける $\mathrm{H} 〉 。 さ$ らに，仕事上時間が制約されるため朝食契食が困難なタ イプが抢り，このタイプが欠食者中最も多かった（結果 (1)に抢ける I )。

渡辺らの調査によると, 男子学生の夕食のピークは 19 時と 22 時の 2 度あることが報告され，これはアルバイト に起因するものではないかとしている17)。本調査でも結 論の I に該当する 9 人すべてが，夜遅くまたは明け方 4 時までアルバイトをすると答えた。このように仕事が夜 遅いことが，朝食欠食の原因と考えられる場合，欠食を なくすための手立てとしてもっとも有効な手段は, 仕事 やアルバイトを日勤に変えることであろう。しかし仕事 を変えることは，学生も含婄らの生活とのものにか かわる問題を含んでいて困難であろう。

以上のことから，食の外部化の高さは朝食欠食者と重 なる者が多く, 若者の食行動の特徵と考えられるが，そ れは必ずしも私生活中心の「生活の乱れ」であるとはい えない。これに対して長時間労働, 深夜労働などが主な 欠食理由の者は 9 人 $(17 \%)$ を占めていた。このことか ら, 今日の若者は学生も含めて, 食の外部化に依存した 就業形態に一定程度就かざるを得ないような状況にいる こと，それが生活スタイルや食意識に影響を及ぼしてい ることが示唆された。

\section{（2）食の外部化と勤務形態別に見た食への満足感}

わが国の栄養供給に打ける量と質は1970年代初めにす でに充足され，過剰時代に入って久しい。20代の若者は 食の第一義的機能が充足された後に生まれ育っている。 このような社会では，食の論議はより高次で形而上的面 に向かう傾向にある18)。

しかしながら，若者で外部化された食への依存傾向が 強い者ほど, 食への関心や要求は食の第一義的機能であ る栄養と健康面に収斂し, 精神的, 文化的な面への関心 は薄れる傾向が見られた。また食の外部化の原因は，就 業形態から派生する生活時間の不規則さや制約が大きい ものの, 食の外部化の程度が低い方が満足感が高いこと がわかった。

以下では，食の外部化，21時以降の就業形態の者が食 に対しどのような食意識を抱いているのかを知るため, 表 3 の A， B， D，Eのなかで夜21時以降の勤務が週 3 回以上ある者（食生活が不規則と考えられる者）と，食 の外部化傾向の高い者 C, $\mathrm{F}$ に注目して考察した。

これに該当する者は 23 人 $(44.2 \%)$ であり，23人の食 生活への満足/不満足による分類は表 $7-1$ の通りであっ た。

23 人のうち A， B，Eの 9 人は外部化は低いが， 21 時

\begin{tabular}{c|c|c|c} 
表 7-1 & \multicolumn{3}{c}{$\begin{array}{l}\text { 夜21時以降の勤務のある者及び食の外部化の高い } \\
\text { (単位, 人) }\end{array}$} \\
\hline 外部化度 & 食生活に満足 & 食生活に不満足 & 合 計 \\
\hline $\mathrm{A}$ & 2 & 0 & 2 \\
$\mathrm{~B}$ & 2 & 3 & 5 \\
$\mathrm{C}$ & $3(2)$ & 0 & $3(2)$ \\
$\mathrm{E}$ & 1 & 1 & 2 \\
$\mathrm{~F}$ & 2 & $9(7)$ & $11(7)$ \\
\hline 合計 & 10 & 13 & 23 \\
\hline
\end{tabular}

$\chi^{2}=9.42 \quad \mathrm{p}<0.05$

表 7-2 表 7-1におけるJグループ（A， B， E の者) と，Kグループ（C，Fの者）の， 食の満足/不満足別分類 (単位, 人)

\begin{tabular}{|c|c|c|c|}
\hline & 満足 & 不満足 & 合計 \\
\hline $\mathrm{J}$, 外部化が低い者 & 5 & 4 & 9 \\
\hline $\mathrm{K}$, 外部化が高い者 & 5 & 9 & 14 \\
\hline 合計 & 10 & 13 & 23 \\
\hline
\end{tabular}

$\chi^{2}=0.87 \quad \mathrm{p}<0.34$

以降も勤務のある者のグループ， C， F の 14 人は外部化 が高いグループというように分けることができる。前者

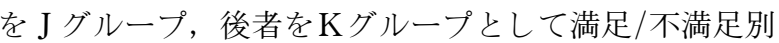
に分けると，表 $7-2$ のようになる。

表 7 - 1，2 加，夜21時以降勤務のある者は食の外 部化の高低にかかわりなく存在すること, 外部化の程度 と食の満足/不満足感とはあまり関係のないことが確認 できる。

$\mathrm{J}$ グループに属する 9 人は, 食の外部化が低い，21時 以降の勤務者である，家族同居者が多い，という共通項 でくくることができるが，食への満足な者もいれば不満 足な者もいる。満足という者の具体的回答を見ると, 現 在就いている仕事に充実感を感じているため, 食事が多 少不規則であっても「満足」であるというものだった。 また不満足の者は勤務形態が食事時間の不足や不規則さ をもたらすなど生活全体に対する不満感が強かった。

これに対してKグループの14人は，外部化度が高い， 夜21時以降の勤務者が多い，一人暮らしが多いという共 通項があり，Jグループ同様食生活に満足している者と していない者がいた。彼らの具体的回答内容から見ると 以下のようであった。

「満足している」と答えた者の具体的回答から, 生活 時間がアルバイトと授業，部活，あるいは仕事そのもの が過密ともいえるスケジュールであり, 生活の重心は食 事よりも仕事やアルバイト，部活動などに置かれ，それ らが優先されていることが伺えた。食事への関心は感性 を通して得られる食の楽しみに対する思いや価值意識は 低く, カロリーがあり, 肉料理などボリュームがあって 
満腹になることが重視される傾向が見られた。さらに彼 らは，栄養的には「乱れた」食事であっても，彼ら自身 は周囲の者や大人が考えるほど「乱れている」あるいは 「劣悪」「問題である」と感じていないのではないかと考 えられた。

「満足していない」と答えた者は満足している者と同 様, 過密な生活時間を送っていることが同えた。しかし 満足している者と異なる点は, 栄養のバランスが悪いこ とへの自覚, 健康上問題が生じることへの懸念, このよ うな状態を改善する必要性を感じていること, さらに自 分で料理したいという欲求を持ち, 食生活改善に対する 意欲が伺える点であった。彼らは，外部化された食事が 増大することに不安とジレンマを感じ, これらの解消, つまり食意識と食行動の乘離している部分を埋めたいと いう意向が感じられた。と同時に彼らが食生活で改善し たいのは「栄養, 健康面」「食事の量や質」「食事時間」 「食事形態」など食の第一義的機能に集中していた。

以上ををとめると次のようになる。

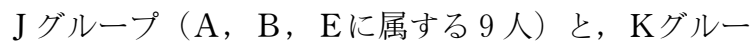
プ（ C， Fに属する14人）を比較すると， J グループの 不満感は食事内容や栄養価などに関するものはあまり見 られず，勤務形態によって食事時間や生活が規制される ことに対するものが多かった。このグループは家族同居 者が多いことから，食事が手作りで栄養的配慮がなされ， 食の第一義的機能は充足されているため，このことが満 足/不満足の内容に反映しているのではないかと思われ る。

これに対して，Kグループでは，満足している者は食 や健康に対する関心が低く，現在の食生活に対する問題 意識も薄い。また, 満足していない者は健康に対する危 機意識, 現在の食事に栄養的偏りがあるので, 改善した いという気持ちを抱いていた。つまり，不満足の者は食 事内容や栄養価など食事の質, つまり食の第一義的機能 が充足されていないため，そのことに対する不満感が強 いこと, 満足な者は実際には食の第一義的機能に問題で あると考えられるのにも関わらず，それが実感できてい ないという点で，Jと異なっていた。

このことから, 若者の食に対する関心は外部化が高い 者で現状に不満足な者は，栄養や健康面の充足欲求が高 いことがわかった。また満足感は勤務形態によって規定 されるよりも, 現在の自分の食を含めた生活全般に対し てどのように感じているのか, 自己の健康や身体状況を どのように実感しているのかに規定されることが示唆さ れた。さらに， Jグループ，Kグループそれぞれ，食に 対する満足/不満足感を持っているという点では同じで あっても, 満足感や不満足感の内容, 質が食の外部化の 程度によって異なっていることがわかった。

\section{5 結 論}

それではこのような結果をどのように受け止め，食物 $66 \quad(66)$
教育にどのように反映させていったらよいだろうか。 近年, ことに都会では夜型労働, 長時間労働, 不安定 . 不定期労働の職種が多様に存在し, 若者は都市生活者の 割合の多いことと年齢, 経験, 熟練度などから,このよ うな雇用形態, 職種に就く, あるいは就かざるを得ない 割合が高くなっている。また, 若者で雇用労働者の場合 はライフコースの観点から, 職業労働を中心とした社会 的活動に最も重点をおく年代である。若者の食の外部化 が増大する背景には，このような社会構造化された雇用 状態があり，それによって食の外部化も社会構造化され ていることがあり，これが食生活の特徵のひとつと考え られる。

さらに, 調査結果から食の外部化を 6 つに類型化した。 このことは若者の食事形態が多様になっていることを示 すものである。また，同じような夜遅い就労形態であっ ても, 食事への満足/不満足感の内容や質が異なってい る，というように食に抱く気持ちも多様になっている。 つまり食形態と食意識の多様化が特徵の二つ目と考えら れる。

そうであるとすれば，これからの食物教育は，小，中 学生とは異なった, 多様な食事形態や食意識に対応した 若者独自の内容と方法が求められる。

これまでの食物教育は, 栄養バランスの取れた食事を 家族で共食するという「理想の食事」を設定し，それに 近づくよう指導するという形が，ほぼ一律に実施されて きた。この従来型の指導内容は今日では栄養や健康をは じめ食への文化的, 心理的関心の高い者, つまり食の外 部化が高くなく，かつ生活が不規則でない者にとっては 適合すると思われる。しかし, 食の外部化の度合いが高 く, 就労形態が深夜に及ぶというような者に「理想」の 食生活像を示したとしても，これに近づくのは難しい。 しかも，食の外部化が高くそれに満足している者のなか には食に対する関心が低い者も拈り，それは健康リスク が高い層と重なる。このような層に対して, 従来型の食 物教育を適応させることは困難であろう。

それでは，これらのケースに対してどのような対処法 があるのだろうか。

一つはこれまでの食物教育の方法と内容を, 伝統的日 本型食事や栄養バランスが取れたものというようにグ レードの高い「理想の食事」を模範にすることから, 個 々の生活に適した食事とはどのようなものかを, 生徒自 身が探求する形態に転換することが考えられる。「理想」 に到達することが食物教育の目的である, という考え方 は普遍性を失っており, 食生活の多様化の時代にともな い「理想」とされる食事は一つではなくなっているから である。一般的に食生活のグレードが上がるほど, 趣味 や嗜好の度合は強まる。そしてこのような教科内容を必 要とする生徒層は一定程度存在するが，そうではない生 徒も増大している。したがって生徒のニーズに即し, 教 科内容を柔軟に変化させる必要が生じてきているのであ 
る。

具体的には, 食の外部化が高い若者に対しては,「理 想の食生活」の代わりに彼らの現実に即した，実現可能 な食生活像, 生活のグレードを落とし, 敷居を低くした 食生活を設定することが望まれる。つまり彼らの生活に 遊離しない内容という点が重要である。具体的にはカッ プラーメンよりもせめて野菜を入れたインスタントラー メンのほうがよいとか，レトルトカレーを食べる場合果 物や生野菜を一緒に食べたほうがよりおいしいとか，ご 飯と味増汁と魚の干物, 豆腐というような, 「格好のつ く食事」の準備ができればよいというものである。最低 限これくらいのことができればいいという知識と技術を 具体的に示し，少しでも実践できるようになれば，外部 化された食事への違和感，健康への危機感や緊張感はか なり緩和されると思われる。また，食への関心の低い者 にとっても, 自分の状況に合わせて簡単なことからはじ め，より颃いしい食事を作る体験によって，自分ででき るレパートリーを徐々に増やしていけるのではないだろ うか。

対処法のもう一つは，これまで食物教育の範疇に入っ ていなかった雇用労働や社会問題にまで踏みこむことで ある。

食べることと雇用はこれまで別問題と考えられてきた。 しかし，若者の状況を見ると両者は分かち難く結びつき， 交錯している。そのため，このような職業を選べば生活 時間の多くが規制され，食事時間も制約されるというよ うに，職業やライフコース選択の段階で，食におけるメ リットとリスクを知らせることなどを, 教育内容に盛り 込むことが考えられる。

\section{引用文献}

1）高橋正朗監, 豊川裕之, 安村碩之: フードシステム学全 集第 1 巻 フードシステム学の理論と体系, 農林統計協会, 東京 (2001)

2）安村碩之, 日暮晃一：2000, 現代の食生活 主婦5827人 に聞く, 学文社, 東京 $(2000)$

3）小林敏生 : 健康の科学シリーズ13 若者の生活, 食·栄 養と健康, 日本衛生学会, 101-114, 大阪 (2004)

4) 石毛直道, 杉田浩一: 講座 食の文化 第 3 巻 調理と 食べもの，財味の素食の文化センター，55，東京（1999）

5）財食料・農業政策研究センター：2003年版食料白書 ラ イフスタイルの変化と食品産業一食の外部化と安全·安心 志向, 農山漁村文化協会, 東京 (2004)

6）健康 - 栄養情報研究会 : 国民栄養の現状（平成14年度厚 生労働省国民栄養調查結果)，第一出版，東京（2004）

7）飯田文子, 高橋智子, 川野亜紀, 渡辺敦子, 大越ひろ, 三輪里子：日本食生活学会誌，12，167-175（2001）

8）渡辺敦子, 飯田文子, 川野亜紀, 大越ひろ, 三輪里子： 日本食生活学会誌， 10，45-52（2000）

9）田辺由紀, 金子佳代子：日本家政学会誌，52，51-60 (2001)

10）梶原公子：日本食生活学会誌，15，178-184（2004）

11）前掲の 7 ）に同じ。

12）前掲の 6 ）に同じ

13）堀田千鶴子：日本食生活学会誌， 8，49-53（1997）

14）田村祐司, 小林敏生, 西村一夫, 脇坂喜代美, 小室理恵 子, 杉崎昭生, 梅村詩子 : 全国大学保健管理施設研究集会 報告書34，148-152（1996）

15）例えば，渡辺正は『朝食をやめて健康になる』（2003知恵 の森文庫）で，朝食抜き健康法を展開している。

16）香川靖男：科学が証明する朝食のすすめ, 女子栄養大学 出版部，東京 (2001)

17）前掲の 8）に同じ。

18）熟田清一:〈食〉は病んでいるのか 摇らぐ生存の条件, ウエッジ選書, 図書印刷, 東京 (2002) 